\title{
Pengaruh Perubahan Organisasi, Budaya Organisasi Dan Perilaku Kerja Terhadap Kinerja Karyawan Di PT. Sisirau Medan
}

\author{
Sunaryo \\ Prodi Manajemen, STIE Harapan Medan \\ Email: sunaryo.dosen@gmail.com
}

\begin{abstract}
ABSTRAK
Tujuan penelitian ini adalah untuk mengetahui pengaruh perubahan organisasi, budaya organisasi dan perilaku kerja terhadap kinerja, Populasi penelitian ini adalah seluruh pegawai dan pimpinan yang bekerja di PT Sisirau Medan yaitu sebanyak 80 orang responden. Sampel yang digunakan pada penelitian ini adalah sampel jenuh, dengan menggunakan seluruh populasi sebagai sampel yaitu sebanyak 80 orang. Data dikumpulkan dengan menggunakan observasi dan kuesioner. Selanjutnya dilakukan uji analisa data dengan menggunakan analisis regresi berganda, uji t, uji $\mathrm{F}$ dan koefisien determinasi. Hasil penelitian ini adalah Perubahan Organisasi berpengaruh signifikan terhadap kinerja karyawan, besarnya pengaruh perubahan organisasi terhadap kinerja pegawai sebesar 95.6\%. Budaya Organisasi berpengaruh signifikan terhadap kinerja karyawan, besarnya pengaruh Budaya Organisasi terhadap kinerja karyawan adalah sebesar $71.2 \%$. Perilaku Kerja berpengaruh signifikan terhadap kinerja karyawan, besarnya pengaruh Perilaku Kerja terhadap kinerja karyawan sebesar 31.2\%. Secara simultan Perubahan Organisasi, Budaya Organisasi, dan Perilaku Kerja berpengaruh signifikan terhadap Kinerja karyawan di PT Sisirau Medan. Besarnya kemampuan Perubahan Organisasi, Budaya Organisasi, dan Perilaku Kerja dalam menjelaskan kinerja adalah sebesar $79.9 \%$ sedangkan sisanya sebesar $20.1 \%$ dijelaskan oleh variabel lain yang tidak dimasukkan ke dalam model penelitian ini.
\end{abstract}

Kata Kunci: Perubahan Organisasi, Budaya Organisasi, Perilaku Kerja, Kinerja

\section{The Influence Of Organizational Change, Organizational Culture And Work Behavior On Employee Performance at PT. Sisirau Medan}

\begin{abstract}
The purpose of this study is to determine the effect of the organizational change, organizational culture and work behavior on performance, The population of this study are all employees and leaders who work in PT Sisirau Medan that is as much as 80 respondents. The sample used in this study is a saturated sample, using the entire population as a sample of 80 people. Data were collected using observations and questionnaires. Furthermore, data analysis is tested by using multiple regression analysis, $t$ test, $F$ test and coefficient of determination. The result of this research is organizational change has a significant effect on employee performance, the influence of organizational change on employee performance is 95.6\%. Organizational Culture has a significant effect on employee performance, the amount of influence of Organization Culture on employee performance is $71.2 \%$. Work Behavior has a significant effect on employee performance, the effect of Work Behavior on employee performance is $31.2 \%$. Simultaneously Organizational Change, Organizational Culture, and Work Behavior have a significant effect on Employee Performance in PT Sisirau Medan. The amount of Organizational Change, Organizational Culture, and Work Behavior in explaining performance is $79.9 \%$ while the remaining $20.1 \%$ is explained by other variables not included in this research model.
\end{abstract}

Keywords: Organizational Change, Organizational Culture, Work Behavior, Performance

How to cite:

Sunaryo. (2017). Pengaruh Perubahan Organisasi, Budaya Organisasi Dan Perilaku Kerja Terhadap Kinerja Karyawan Di PT Sisirau Medan. Jurnal Ilmiah Manajemen \& Bisnis, 18(1), 101-114. 


\section{PENDAHULUAN}

Perubahan organisasi menyebabkan adanya pekerjaan yang dikerjakan belum selesai harus terhenti sejenak dan nanti dilanjutkan oleh orang lain. Hal - hal seperti ini memang menjadi kendala, pekerjaan yang seharusnya dapat diselesaikan dengan segera akan terhenti oleh karena adanya sistem rekstrukturisasi pada organisasi. Tujuan utama dari perubahan organisasi tersebut sebenarnya adalah untuk meningkatkan kinerja perusahaan yang akhirnya adalah pencapaian tujuan perusahaan secara maksimal. Dengan perubahan organisasi juga diharapkan bahwa terjadi peningkatan kemampuan manajemen perusahaan dalam memaksimalkan semua potensi sumber daya yang dimiliki oleh perusahaan. Namun ketika perubahan organisasi yang dilakukan tidak maksimal tentunya akan menjadi masalah bagi perusahaan itu sendiri, sehingga perubahan organisasi akan menjadikan rendahnya kinerja karyawan. Selanjutnya Kisdarto (2000:23) menyatakan kinerja pegawai tentunya sangat dipengaruhi oleh budaya kerja manusia yang ada di organisasi. Harus disadari pula bahwa budaya erat kaitannya dengan manusia. Variabel yang diduga menyebabkan rendahnya kinerja pegawai adalah perilaku kerja pegawai itu sendiri. Perilaku adalah satu hasil dari peristiwa atau proses belajar. Perilaku kerja yang baik dari pegawai akan dapat meningkatkan kinerja pegawai. Diketahui bahwa perilaku kerja pegawai dipengaruhi oleh lingkungan dan budaya organisasi yang terbentuk dari perusahaan itu sendiri.

\section{KAJIAN TEORI \\ Perubahan Organisasi}

Beberapa definisi dari perubahan organisasi pada umumnya tidak terlepas dari reorganisasi dan perubahan organisasi itu sendiri.

$$
\text { Djohanputro }
$$
menyebutkan bahwa perubahan organisasi merupakan penyusunan ulang komposisi manajemen, struktur organisasi, pembagian kerja, sistem operasional dan hal-hal lain tertentu yang berkaitan dengan masalah manajerial dan keorganisasian. Sedangkan Savage dalam Sedarmayanti (1999:57) mengemukakan bahwa perubahan organisasi sebagai pengejawantahan dari generasi kelima manajemen, yaitu manajemen yang berbasis kepada dynamic teamming, knowledge networking, cross border atau out of board serta virtual enterprises. Kesemuanya itu mengarah kepada suatu kesepakatan bahwa mengelola organisasi pada jaman modern seperti sekarang tidak mungkin lagi hanya mengandalkan kepada teknik konvensional seperti struktur mekanistik maupun jalur perintah yang panjang dan rumit. Sebaliknya, organisasi harus diperlakukan secara luwes dan fleksibel, memperbesar pendelegasian wewenang, memacu peran dan tanggungjawab staf fungsional, serta memiliki rentang kendali (spend of control) yang tidak terlalu panjang.

Perubahan organisasi mempunyai manfaat bagi kelangsungan hidup suatu organisasi, karena tanpa adanya perubahan dapat dipastikan usia organisasi itu tidak akan bertahan lama. Perubahan organisasi bertujuan agar organisasi tidak menjadi statis dengan kemajuan teknologi. Tujuan utama dari terjadinya perubahan adalah untuk meningkatkan kemampuan organisasi dan semua orang yang ada di dalam organisasi, yang pada gilirannya tercermin dalam peningkatan kemampuan organisasi secara keseluruhan. Menurut Siagian (2003:21) menyatakan tujuan perubahan organisasi adalah sebagai berikut :

1. Meningkatkan kemampuan organisasi untuk menampung dampak dari perubahan yang terjadi dalam berbagai bidang yang terjadi di luar organisasi

2. Meningkatkan peranan organisasi dalam menentukan arah perubahan yang mungkin terjadi 
3. Melakukan penyesuaian-penyesuaian secara intern demi peningkatan kemampuan

4. Meningkatkan daya tahan organisasi, bukan saja mampu tetap bertahan akan tetapi juga untuk terus bertumbuh dan berkembang.

5. Mengendalikan suasana kerja sedemikian rupa sehingga para anggota organisasi tetap merasa aman dan terjamin meskipun terjadi perubahanperubahan di dalam dan diluar organisasi.

Sedangkan menurut Djohanputro (2004:2) tujuan dari perubahan organisasi untuk memperbaiki dan memaksimalkan kinerja perusahaan, sedangkan tujuan lainnya adalah:

1. Meningkatkan kinerja dan nilai perusahaan

2. Memberikan manfaat dividen dan pajak terhadap negara

3. Menghasilkan produk dan layanan dengan harga kompetitif kepada konsumen

4. Memudahkan pelaksanaan privatisasi

Menurut beberapa ahli, nilai-nilai perubahan organisasi yang berkembang dalam organisasi dan mungkin sedikit berbeda dengan nilai-nilai yang ada yang berkembang pada organisasi atau birokrasi di Indonesia adalah :

1. Nilai yang berorientasi pada humanis

2. Menghargai pendapat

3. Konflik harus diangkat ke permukaan

4. Spirit penelitian

5. Bebas berbeda pendapat dengan pimpinan

6. Diberi kesempatan beristirahat

7. Dijamin adanya partisipasi dalam pengambilan keputusan

\section{Budaya Organisasi}

Budaya organisasi berkaitan dengan bagaimana karyawan mempersepsikan karakteristik dari budaya suatu organisasi, bukannya dengan apakah mereka menyukai budaya itu atau tidak. Artinya, budaya itu merupakan suatu istilah deskriptif. Budaya organisasi merupakan suatu persepsi bersama yang dianut oleh semua anggota organisasi. Untuk lebih jelasnya pengertian budaya organisasi berikut ini akan dikemukakan pendapat beberapa ahli perilaku organisasi. Kreitner dan kinicki (2003:79) menyatakan : "Budaya organisasi adalah salah satu wujud anggapan yang dimiliki, diterima secara implisit oleh kelompok dan menentukan bagaimana kelompok tersebut rasakan, pikirkan dan bereaksi terhadap lingkungannya yang beraneka ragam".

Lebih lanjut Robbins (2001:150) menyatakan bahwa sebuah sistem makna bersama dibentuk oleh para warganya yang sekaligus menjadi pembeda dengan organisasi lain. Sistem pemaknaan bersama merupakan seperangkat karakter kunci dari nilai-nilai organisasi. Dalam hal ini Robbins memberikan 7 (tujuh) karakteristik budaya organisasi (2001:152) sebagai berikut :

1. Inovasi dan keberanian mengambil resiko

Sejauh mana karyawan didukung untuk menjadi inovatif dan mengambil resiko.

2. Perhatian terhadap detail

Sejauh mana karyawan diharapkan menunjukkan kecermatan, analisis dan perhatian terhadap detail.

3. Berorientasi pada hasil

Sejauh mana manajemen memfokus pada hasil bukannya pada teknik dan proses yang digunakan untuk mencapai hasil tersebut

4. Berorientasi kepada manusia

Sejauh mana keputusan manajemen memperhitungkan efek pada orangorang di dalam organisasi itu.

5. Berorientasi pada tim

Sejauh mana kegiatan kerja diorganisasikan sekitar tim-tim, ukannya individu.

6. Agresivitas

Berkaitan dengan agresivitas karyawan. 
7. Stabilitas

Organisasi

menekankan

dipertahankannya budaya organisasi yang sudah baik.

\section{Perilaku Kerja}

Perilaku kerja adalah bagian yang sangat penting dalam kehidupan bekerja organisasi, perilaku kerja merupakan tindakan dan sikap yang ditunjukkan oleh orang-orang yang bekerja. Menurut Bond dan Freid dalam Manullang (2010:15) perilaku kemampuan kerja dan perilakuperilaku dimana hal tersebut sangat penting di setiap pekerjaan atau situasi kerja. Perilaku merupakan proses cara seseorang mengerjakannya. Perilaku merupakan sebuah unsur yang menjadi pusat perbedaan manusia. Dalam pekerjaan, tanpa perilaku tidak akan ada produksi. Perilaku merupakan kata kunci, sebab dalam pekerjaan sangat banyak perilaku yang muncul yang menyebabkan sebuah hasil tertentu. Perilaku dapat diobservasi sehingga kita dapat membetulkan, menjumlah, menilai dan selanjutnya agar dapat dikelola. Jika seorang manajer menaruh perhatiannya hanya pada pengelolaan hasil saja tidak akan selalu efektif, karena perilaku merupakan bagian dari keseluruhan proses dan hasil itu adalah keluaran dari perilaku.

Keberhasilan di berbagai wilayah kehidupan ternyata juga ditentukan oleh perilaku manusia, terutama perilaku kerja. Sebagian orang menyebut perilaku kerja ini sebagai motivasi, kebiasaan (habit) dan budaya kerja. Diupayakan untuk membentuk perilaku kerja yang konsisten dan positif. Menurut Sinamo dan Santoso dalam Hattami Amar (2011:18) ada delapan paradigma tingkat perilaku kerja yang membuahkan delapan perilaku kerja utama yang sanggup menjadi basis keberhasilan baik ditingkat pribadi organisasional maupun sosial, yaitu; bekerja tulus, bekerja tuntas, bekerja benarm bekerja keras, bekerja serius, bekerja kreatif, bekerja unggul dan bekerja sempurna.

Menurut Wathon dan Yamit dalam Hattami Amar (2011:23) menyatakan indikator perilaku kerja terdiri dari dari semangat dan kegairahan kerja, daya inisiatif kerja, keterlibatan kerja, dan keterikatan terhadap organisasi. Sedangkan menurut Bryson dalam Hattami Amar (2011:25) berpendapat bahwa ada empat indikator yang mempengaruhi perilaku kerja yaitu :

1. Kemampuan berhubungan sosial,

2. Kualitas pekerjaan yang artinya para pekerja harus menunjukkan kualitas kerja yang baik agar dapat diakui dan dihargai

3. Kebiasaan kerja, dihubungkan dengan perilaku yang positif dan negatif ditempat kerja

4. Pengendalian diri, tidak menjadi murah marah atau agresif dan tidak berperilaku aneh yang artinya ditempat kerja harus dapat mengendalikan diri dan menunjukkan pribadi yang profesional dalam bekerja.

\section{Kinerja}

Dalam melaksanakan kerja, karyawan menghasilkan sesuatu yang disebut kinerja. Kinerja merupakan hasil kerja seorang karyawan selama periode tertentu dibandingkan dengan berbagai kemungkinan misalnya standar, target/sasaran atau kriteria yang telah ditentukan terlebih dahulu dan disepakati bersama. Menurut Mangkunegara (2000:67) "kinerja adalah hasil kerja secara kualitas dan kuantitas yang dicapai oleh seorang karyawan dalam melaksanakan tugasnya sesuai dengan tanggungjawab yang diberikan kepadanya". Sedangkan Mathis dan Jackson (2002:78) berpendapat bahwa "kinerja pada dasarnya adalah apa yang dilakukan atau tidak dilakukan karyawan". Kinerja karyawan adalah yang mempengaruhi seberapa banyak mereka 


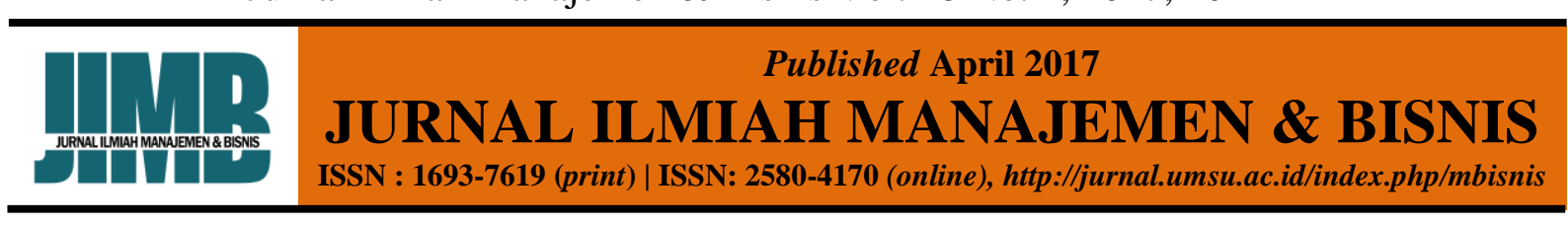

memberikan kontribusi kepada organisasi yang antara lain termasuk kuantitas output, kualitas output, jangka waktu output, kehadiran di tempat kerja, dan sikap kooperatif. Menurut Sastrohadiwiryo (2002:231), penilaian kinerja adalah suatu kegiatan yang dilakukan manajemen/penyelia untuk menilai kinerja tenagakerja dengan cara membandingkan kinerja atas kinerja dengan uraian/deskripsi pekerjaan dalam suatu periode tertentu yang biasanya setiap akhir tahun. Kegiatan ini dimaksudkan untuk mengukur kinerja masing - masing tenaga kerja dalam mengembangkan kualitas kerja, pembinaan selanjutnya, tindakan perbaikan atas pekerjaan yang kurang sesuai dengan deskripsi pekerjaan, serta untuk keperluan yang berhubungan dengan masalah ketenagakerjaan lainnya. Penilaian kinerja terhadap tenaga kerja biasanya dilakukan oleh manajemen/penyelia yang hirarkinya langsung di atas tenaga kerja yang bersangkutan atau manajemen/penyelia yang ditunjuk untuk itu.

Manajemen kinerja dapat dipahami suatu proses yang dirancang untuk memperbaiki kinerja organisasi melalui perbaikan kinerja individu dan kelompok. Menurut Anoraga (2004:178) ada faktor faktor yang mempengaruhi kinerja karyawan adalah sebagai berikut:

1. Motivasi

Pimpinan organisasi perlu mengetahui motivasi kerja dari anggota organisasi karyawan. Dengan mengetahui motivasi itu maka pimpinan dapat mendorong karyawan bekerja lebih baik.

2. Pendidikan

Pada umumnya seseorang mempunyai pendidikan lebih tinggi akan mempunyai kinerja yang lebih baik, hal demikian ternyata merupakan syarat yang penting dalam meningkatkan kinerja karyawan. Tanpa bekal pendidikan, mustahil orang akan mudah dalam mempelajari hal - hal yang bersifat baru dalam cara atau suatu sistem.

3. Disiplin Kerja

Disiplin kerja adalah sikap kejiwaan seseorag atau kelompok yang senantiasa berkehendak untuk mengikuti atau mematuhi segala peraturan yang telah ditentukan. Disiplin kerja mempunyai hubungan yang sangat erat dengan motivasi, kedisiplinan dengan suatu latihan antara lain dengan bekerja menghargai waktu dan biaya akan memberikan pengaruh yang positif terhadap kinerja karyawan

4. Keterampilan

Keterampilan banyak pengaruhnya terhadap kinerja karyawan. Keterampilan karyawan dalam perusahaan dapat ditingkatkan melalui training, kursus - kursus dan lain - lain.

5. Budaya Kerja

Sikap seseorang atau kelompok orang dalam membina hubungan yang serasi, selaras, dan seimbang di dalam kelompok maupun dengan kelompok lain. Budaya kerja sangat penting karena dengan tercapainya hubungan seimbang antara perilaku dalam produksi akan meningkatkan kinerja.

6. Gizi dan Kesehatan

Daya tahan tubuh seseorang biasanya dipengaruhi oleh gizi dan makanan yang didapat, hal ini mempengaruhi kesehatan karyawan, dengan semua itu akan berpengaruh terhadap kinerja karyawan.

7. Tingkat penghasilan

Penghasilan yang cukup berdasarkan prestasi kerja karyawan karena semakin tinggi prestasi karyawan maka semakin besar penghasilan yang diterima.

8. Lingkungan kerja dan iklim kerja

Lingkungan kerja dari karyawan termasuk hubungan kerja antara karyawan, hubungan dengan pimpinan, suhu serta lingkungan penerangan dan 
sebagainya. Hal ini sangat penting untuk mendapatkan perhatian dari perusahaa karena sering karyawan enggan bekerja, karena tidak ada kekompakkan dalam kelompok kerja

9. Teknologi

Dengan adanya kemajuan teknologi yang meliputi peralatan yang semakin otomatis dan canggih akan mendapat dukungan tingkat produksi dan mempermudah manusia dalam melaksanakan kegiatan

10. Sarana Produksi

Faktor - faktor produksi harus memadai dan saling mendukung dalam proses produksi

11. Jaminan Sosial

Perhatian dan pelayanan perusahaan kepada setiap karyawan menunjang kesehatan dan keselamatan. Dengan harapan agar karyawan semakin bergairah dan mempunyai semangat untuk bekerja

12. Kepemimpinan

Dengan adanya kepemimpinan yang baik maka karyawan akan berorganisasi dengan baik, dengan demikian kinerja akan tercapai.

13. Kesempatan berprestasi

Setiap orang dapat mengembangkan potensinya yang ada dalam dirinya, dengan diberikan kesempatan berprestasi, maka karyawan akan meningkatkan kinerja.

\section{Kerangka Konseptual}

Pendapat dari Sugiono (2002:49) yang memberikan pengertian kerangka konseptual atau kerangka berfikir, "yaitu merupakan sintesa tentang hubungan antara variabel yang disusun dari berbagai teori yang telah di deskripsikan". Hubungan variabel yang terjadi, dihubungkan melalui indikator - indikator dari setiap variabel. Untuk lebih jelas tentang kerangka konseptual penelitian ini, dapat dilihat pada gambar berikut ini:

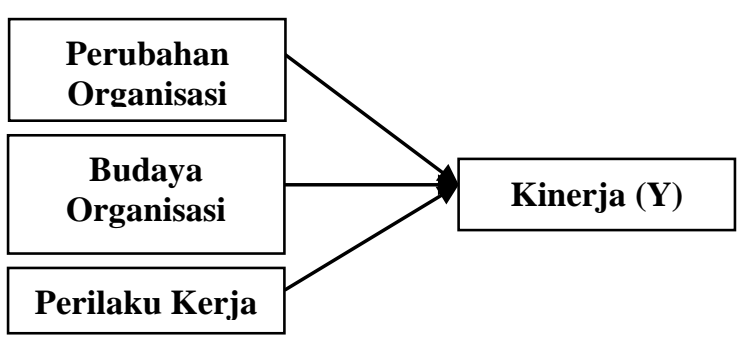

Gambar 1. Kerangka Konseptual

\section{Hipotesis}

Hipotesis merupakan jawaban sementara atas hasil penelitian penelitian. Hipotesis merupakan jawaban sementara masalah penelitian yang kebenarannya harus diuji secara empiris. Berdasarkan pada gambar kerangka konseptual penelitian ini, maka dapat disusun hipotesis penelitian ini adalah sebagai berikut:

1. Terdapat pengaruh yang positif dan signifikan perubahan organisasi terhadap kinerja karyawan di PT Sisirau Medan

2. Terdapat pengaruh yang positif dan signifikan budaya organisasi terhadap kinerja karyawan di PT Sisirau Medan

3. Terdapat pengaruh yang positif dan signifikan perilaku kerja terhadap kinerja karyawan di PT Sisirau Medan

4. Terdapat pengaruh yang positif dan signifikan perubahan organisasi, budaya organisasi dan perilaku kerja terhadap kinerja karyawan di PT Sisirau Medan.

\section{METODE}

Secara ekperimental operasional variabel adalah defenisi yang dikemukakan atas sifat-sifat hal yang didefenisikan yang dapat diamati. Dalam penelitian ini terdiri dari dua variabel, satu variabel bebas (X) dan satu variabel terikat (Y). Variabel bebas dalam penelitian ini adalah perubahan organisasi $\left(\mathrm{X}_{1}\right)$, budaya organisasi $\left(\mathrm{X}_{2}\right)$ dan Perilaku Kerja $\left(\mathrm{X}_{3}\right)$ sedangkan variabel terikat adalah kinerja (Y). Pupolasi yang menjadi populasi dalam penelitian ini adalah 


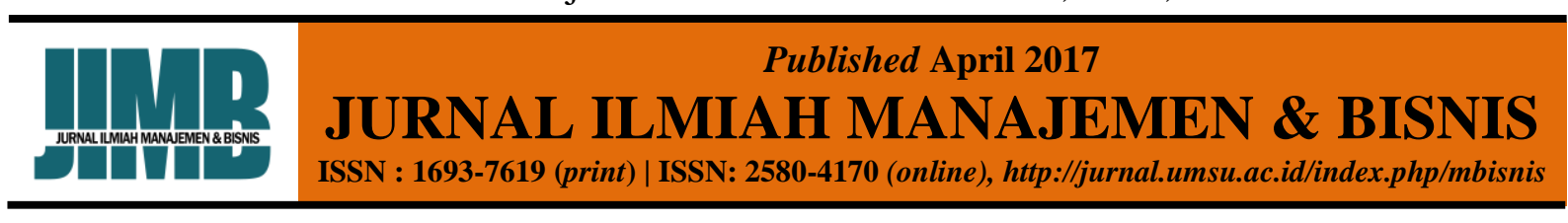

pegawai yang bertugas di PT Sisirau Medan, yang berjumlah 80 orang, sedangkan sampel dalam penelitian ini menggunakan secara keseluruhan populasi yang akan dijadikan sampel penelitian sebanyak 80 orang. Data dalam penelitian ini terdiri dari data primer yaitu Observasi, dan Angket (quesionnaire). Sedangkan data sekunder yaitu mengumpulkan data-data yang dibutuhkan dari dokumen yang dimiliki oleh PT Sisirau Medan. Penelitian ini adalah penelitian kuantitatif dengan metode analisis regresi berganda. Sebelum dilakukan analisis maka akan dilakukan Uji Validitas, uji reliabilitas dan dilanjutkan dengan Uji Asumsi Klasik yang terdiri dari Uji Normalitas, Uji Heteresdekositas, Uji Multikolinieritas.

\section{HASIL DAN PEMBAHASAN Uji Validitas}

Uji ini dilakukan dengan tujuan untuk mengukur ketepatan suatu pertanyaan penelitian dapat menguji suatu model dalam penelitian ini. Berdasarkan hasil uji validitas dengna menggunakan SPSS dapat diketahui bahwa seluruh instrument memiliki nilai $\mathrm{r}_{\text {hitung }}$ lebih besar dibandingkan dengan nilai $\mathrm{r}_{\text {tabel }}$ kecuali pada item pertanyaan kuesioner variabel kinerja kesebelas yang memiliki nilai $r_{\text {hitung }}$ sebesar 0.150 lebih kecil dari 0.183. Sehingga disimpulkan bahwa seluruh instrument pada penelitian ini dapat digunakan atau mampu untuk mengukur setiap variabel pada penelitian ini kecuali item pertanyaan untuk kuesioner variabel yang kesebelas.

\section{Uji Reliabilitas}

Pengujian ini dilakukan untuk menjamin instrumen yang digunakan merupakan sebuah instrumen handal, konsisten, stabil dan dependibalitas, sehingga apabila digunakan berulang-ulang maka akan menghasilkan yang sama. Diperoleh hasil reliabilitas dalam penelitian ini adalah untuk variabel Perubahan Organisasi sebesar 0,604, Budaya Organisasi Sebesar 0,604, Perilaku Kinerja 0,648 dan Kinerja sebesar 0,660 , nilai Cronbach Alpha hitung pada setiap variabel penelitian memiliki nilai yang lebih besar dibandingkan dengan nilai Cronbach Alpha Toleransi, sehingga dapat disimpulkan bahwa variabel - variabel penelitian ini telah lolos uji reliabilitas, karena reliabilitas yang tinggi ditunjukkan dengan nilai 1 , reliabilitas dianggap sudah cukup memuaskan atau tinggi adalah lebih besar atau sama dengan 0,60 . Untuk pengujian ini dilakukan dengan teknik Cronbach Alfa.

\section{Uji Asumsi Klasik}

Pengujian asumsi klasik dilakukan agar menghasilkan estimasi yang minimum dan Best Linear Unbiased Estimation (BLUE). Beberapa uji asumsi klasik yang digunakan pada penelitian ini dapat dilihat seperti pada uraian berikut ini:

\section{Uji Normalitas}

Untuk menyakinkan pengujian normalitas ini penulis menggunakan uji Kolmogorov-Smirnov yang dapat dilihat pada tabel 5 berikut ini:

Tabel 1. Hasil Uji Normalitas

One-Sample Kolmogorov-Smirnov Test

\begin{tabular}{|c|c|c|}
\hline & & $\begin{array}{l}\text { Unstandardized } \\
\text { Residual }\end{array}$ \\
\hline $\mathrm{N}$ & & 80 \\
\hline \multirow[t]{2}{*}{ Normal Parameters ${ }^{a}$} & Mean & .0000000 \\
\hline & Std. Deviation & 2.06013073 \\
\hline \multirow[t]{3}{*}{ Most Extreme Differences } & Absolute & .078 \\
\hline & Positive & .063 \\
\hline & Negative & -.078 \\
\hline Kolmogorov-Smirnov Z & & .698 \\
\hline Asymp. Sig. (2-tailed) & & .715 \\
\hline
\end{tabular}




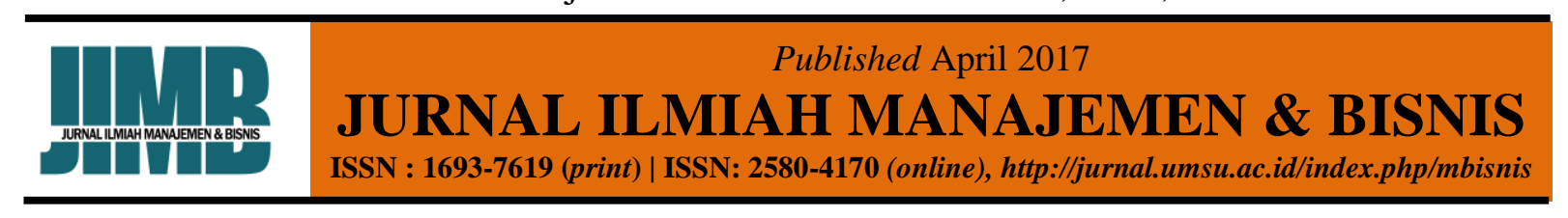

Data akan dikatakan normal jika nilai Asymp.sig (2-tailed) lebih besar dari nilai alpha penelitian $(0,05)$. Tabel 4.10 menunjukkan bahwa nilai Asymp.sig (2tailed) adalah sebesar 0.715 lebih besar dari 0,05 . Maka disimpulkan bahwa data telah terdistribusi secara normal, dengan demikian maka data dapat digunakan selanjutnya untuk mengestimasi kondisi setiap variabel penelitian.
Uji Multikolinearitas

Dalam melakukan pengujian Multikolinearitas digunakan pola membandingkan nilai VIF, dimana nilai VIF lebih kecil dari 10. Untuk melihat uji Multikolinearitas ini, dapat dilihat pada tabel berikut ini:

Tabel 2. Uji Multikolinearitas

\begin{tabular}{|ll|r|r|}
\hline \multirow{2}{*}{ Model } & & \multicolumn{2}{|c|}{ Collinearity Statistics } \\
\cline { 3 - 4 } & & Tolerance & \multicolumn{1}{c|}{ VIF } \\
\hline 1 & (Constant) & & \\
& X1 & .623 & 1.604 \\
X2 & .639 & 1.566 \\
& X3 & .964 & 1.038 \\
\hline
\end{tabular}

Tabel 2 diketahui bahwa nilai VIFnya bahwa variabel telah terbebas dari masalah Multikolinearitas. Hal ini diketahui bahwa nilai VIF Perubahan Organisasi sebesar 1.604, nilai VIF Budaya Organisasi sebesar 1.566 dan nilai VIF Perilaku Kerja adalah sebesar 1.038 lebih kecil dari 10 .

\section{Uji Heteroskedastisitas}

Untuk melihat uji heterokedastisitas penelitian ini, dapat dilihat pada gambar berikut ini:

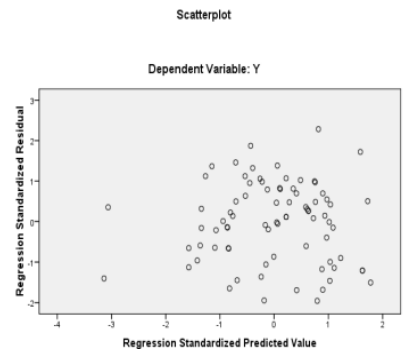

Gambar 2. Uji Heteroskedastisitas
Gambar 2 menunjukkan bahwa titik - titik yang terdapat pada gambar telah menyebar diantara titik 0 pada kotak gambar scatterplot diatas. Ini mengindikasikan bahwa data telah terpenuhi asumsi heterokedastisitas atau dengan kata lain bahwa data telah terbebas dari masalah heterokedastisitas.

\section{Analisis Regresi Linear Berganda}

Adapun hasil estimasi Perubahan Organisasi, Budaya Organisasi dan Perilaku Kinerja berkorelasi dengan Kinerja adalah sebagai berikut: 


\section{Tabel 3 Analisis Regresi Linear Berganda}

\begin{tabular}{|ll|r|r|r|r|}
\hline & & \multicolumn{2}{|c|}{$\begin{array}{c}\text { Unstandardized } \\
\text { Coefficients }\end{array}$} & & \\
\cline { 3 - 4 } Model & & \multicolumn{1}{|c|}{$\mathrm{B}$} & \multicolumn{1}{|c|}{ Std. Error } & \multicolumn{1}{c|}{$\mathrm{t}$} & \multicolumn{1}{c}{ Sig. } \\
\hline 1 & (Constant) & 3.891 & 3.126 & 1.245 & .217 \\
& X1 & .956 & .133 & 7.190 & .000 \\
& X2 & .712 & .084 & 8.466 & .000 \\
& X3 & .312 & .140 & 2.223 & .029 \\
\hline
\end{tabular}

a. Dependent Variable: $Y$

Tabel 3 di atas dapat diketahui model regresi linear berganda yaitu:

$$
\begin{gathered}
Y=3.891+0,956 X_{1}+0,712 X_{2}+ \\
0.312 X_{3}+e
\end{gathered}
$$

Persamaan regresi linear berganda di atas dapat diinterpretasikan sebagai berikut:

1. Jika Perubahan Organisasi, Budaya Organisasi dan Perilaku Kerja tidak mengalami perubahan atau bernilai tetap, maka kinerja akan bernilai sebesar 3.891.

2. Jika Perubahan Organisasi ditingkatkan sebesar 1\%, maka akan diikuti dengan peningkatan Kinerja sebesar $0.956 \%$ dengan asumsi bahwa variabel-variabel lainnya pada penelitian ini bernilai tetap (tidak berubah)
3. Jika Budaya Organisasi ditingkatkan sebesar 1\%, maka akan diikuti dengan peningkatan Kinerja sebesar $0.712 \%$ dengan asumsi bahwa variabel-variabel lainnya pada penelitian ini bernilai tetap (tidak berubah).

4. Jika Perilaku Kerja ditingkatkan sebesar $1 \%$, maka akan diikuti dengan peningkatan Kinerja sebesar $0.312 \%$ dengan asumsi bahwa variabel-variabel lainnya pada penelitian ini bernilai tetap (tidak berubah)

\section{Pengujian Hipotesis \\ Uji t}

Untuk melihat hasil pengujian hipotesis secara parsial (uji t), dapat dilihat pada tabel berikut ini:

Tabel 4 Uji Parsial (Uji t)

\begin{tabular}{|ll|r|r|}
\hline & & & \\
Model & & $\mathrm{t}$ & \multicolumn{1}{c|}{ Sig. } \\
\hline 1 & (Constant) & 1.245 & .217 \\
& X1 & 7.190 & .000 \\
& X2 & 8.466 & .000 \\
& X3 & 2.223 & .029 \\
\hline
\end{tabular}

Berdasarkan pada tabel 8 dapat dilihat bahwa nilai signifikansi dari Perubahan Organisasi adalah sebesar 0.000. Nilai signifikansi tersebut lebih kecil dari nilai
Alpha (0.05), dengan demikian dapat disimpulkan bahwa Perubahan Organisasi berpengaruh signifikan terhadap Kinerja. Selanjutnya pada variabel Budaya 


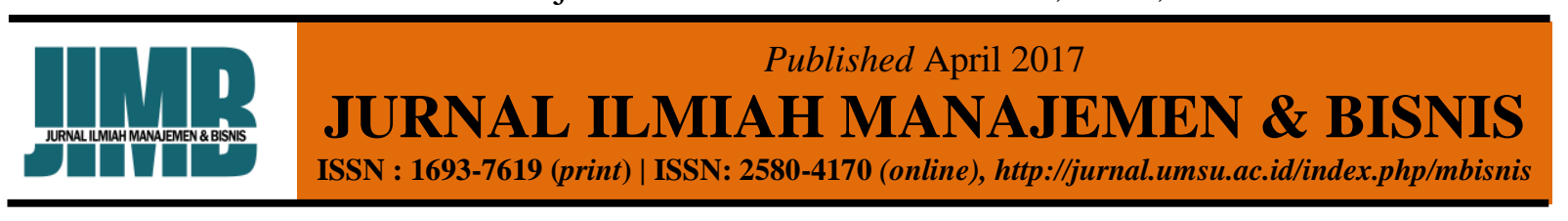

Organisasi diketahui bahwa nilai signifikansi adalah sebesar 0.000. Nilai signifikansi tersebut lebih kecil dari pada nilai Alpha (0.05), dengan demikian dapat disimpulkan bahwa Budaya Organisasi berpengaruh signifikansi terhadap Kinerja. Dan pada variabel Perilaku Kerja diketahui nilai signifikansi adalah sebesar 0.029. Nilai signifikansi tersebut lebih kecil dari nilai Alpha (0.05), dengan demikian dapat disimpulkan bahwa Perilaku Kerja berpengaruh signifikan terhadap Kinerja.

\section{Uji F}

Hasil pengujian secara simultan dapat dilihat seperti pada tabel berikut ini

Tabel 5 Hasil Uji F (Simultan)

ANOVA $^{\mathrm{D}}$

\begin{tabular}{|l|r|r|r|r|r|}
\hline Model & \multicolumn{1}{c|}{$\begin{array}{c}\text { Sum of } \\
\text { Squares }\end{array}$} & \multicolumn{1}{c|}{ df } & \multicolumn{1}{c|}{$\begin{array}{c}\text { Mean } \\
\text { Square }\end{array}$} & F & Sig. \\
\hline 1 Regression & 1336.913 & 3 & 445.638 & 101.013 & $.000^{2}$ \\
Residual & 335.287 & 76 & 4.412 & & \\
Total & 1672.200 & 79 & & & \\
\hline
\end{tabular}
a. Predictors: (Constant), X3, X2, X1
b. Dependent Variable: $Y$

Tabel 5 menunjukkan bahwa nilai signifikansi adalah sebesar 0.000. Nilai signifikansi tersebut lebih kecil dibandingkan dengan nilai Alpha sebesar 0.05. Sehingga dapat disimpulkan bahwa secara bersama - sama Perubahan Organisasi, Budaya Organisasi, Perilaku Kerja berpengaruh signifikan terhadap Kinerja.

\section{Koefisien Determinasi}

Untuk mengetahui seberapa besar variabel Perubahan Organisasi, Budaya Organisasi dan Perilaku Kerja mampu menjelaskan kinerja, maka dilakukan penghitungan koefisiensi determinasi. Adapun hasil Koefisien determinasi dapat dilihat pada tabel dibawah ini:

Tabel 6 Koefisien Determinasi

Model Summary ${ }^{\circ}$

\begin{tabular}{|l|r|r|r|c|}
\hline Model & R & R Square & \multicolumn{1}{|c|}{$\begin{array}{c}\text { Adjusted R } \\
\text { Square }\end{array}$} & $\begin{array}{c}\text { Std. Error of the } \\
\text { Estimate }\end{array}$ \\
\hline 1 & $.894^{\mathrm{a}}$ & .799 & .792 & 2.10040 \\
\hline
\end{tabular}

a. Predictors: (Constant), X3, X2, X1

b. Dependent Variable: $Y$

Tabel 9 dapat dilihat juga bahwa nilai dari Adjusted R Square sebesar 0,792 atau $79,2 \%$ yang menunjukkan bahwa variabel Perubahan Organisasi, Budaya Organisasi dan Perilaku Kerja dalam penelitian ini mampu menerangkan Kinerja di PT Sisirau Medan adalah sebesar 79,2\%. Sedangkan sisanya sebesar $20,8 \%$ dijelaskan oleh variabel - variabel lain yang tidak dimasukkan dalam model penelitian ini.

Pembahasan

Pengaruh Perubahan Organisasi
Terhadap Kinerja Hasil menunjukkan bahwa Perubahan Organisasi berpengaruh 
signifikan terhadap kinerja. Hal ini ditunjukkan dengan nilai signifikansi perubahan organisasi dibandingkan dengan nilai alpha penelitian. Hasil ini menunjukkan bahwa setiap terjadinya perubahan pada perubahan organisasi, maka secara langsung akan mempengaruhi kinerja pegawai. Besarnya pengaruh perubahan organisasi terhadap kinerja adalah sebesar 95.6\% lebih dominan dibandingkan dengan variabel lainnya, sedangkan hubungan yang tercipta diantara perubahan organisasi dengan kinerja adalah hubungan yang positif dan searah. Hasil ini mengindikasikan bahwa ketika pimpinan melakukan perubahan struktur terhadap suatu bidang pekerjaan akan berdampak dengan kinerja dari pegawai. Setiap pegawai yang sudah mendapatkan informasi akan mengalami promosi atau mutasi, akan mengalami penurunan kinerja, sebab akan lebih fokus menunggu pekerjaan yang baru dibandingkan dengan fokus menyelesaikan pekerjaan yang sedang berjalan. Hal ini menyebabkan pekerjaan pada bahagian yang lain akan tersendat, ketika pekerjaan yang tidak selesai karena adanya mutasi atau promosi tidak selesai.

Hasil penelitian ini jelas mendukung hasil penelitian yang dilakukan oleh Toni Rizal Manullang (2011) yang menyatakan bahwa restrukturisasi berpengaruh positif dan signifkan terhadap kinerja pegawai. Dengan demikian semakin menguatkan bahwa perubahan organisasi akan berdampak terhadap kinerja pegawai.

\section{Pengaruh Budaya Organisasi Terhadap Kinerja}

Hasil menunjukkan bahwa Budaya Organisasi berpengaruh signifikan terhadap kinerja. Hal ini ditunjukkan dengan nilai signifikansi Budaya Organisasi dibandingkan dengan nilai alpha penelitian. Hasil ini menunjukkan bahwa setiap terjadinya perubahan pada budaya organisasi, maka secara langsung akan mempengaruhi kinerja pegawai. Besarnya pengaruh budaya organisasi dalam mempengaruhi kinerja adalah sebesar $71.2 \%$, sedangkan hubungan yang tercipta antara budaya organisasi dengan kinerja adalah hubungan yang positif searah. Hal ini mengindikasikan bahwa budaya organisasi sangat penting. Budaya Organisasi yang dapat sebutkan yang sangat dominan dalam mempengaruhi kinerja adalah tingkat kedisiplinan pegawai. Setiap pegawai yang disiplin secara otomatis akan dapat meningkatkan kinerjanya. Pegawai yang disiplin secara otomatis akan berusaha untuk meningkatkan kinerjanya, mengikuti aturan yang sudah ditetapkan oleh pimpinan, dan berusaha untuk tidak berbuat salah.

Budaya organisasi yang lain yang dapat disebutkan adalah saling bekerjasama dan saling membantu terhadap pekerjaan rekan kerja yang sedang mengalami halangan untuk menyelesaikan pekerjaan. Setiap rekan yang membantu rekan lainnya menciptakan budaya organisasi yang sangat baik, sehingga setiap pekerjaan akan dapat selesai dengan tepat waktu tanpa harus menunggu pekerjaan bagian yang lain. Pimpinan perusahaan seharusnya dapat menciptakan budaya organisasi ini lebih baik lagi. Sebab dengan budaya organisasi yang seperti ini, memberikan bentuk budaya organisasi yang sangat baik dengan memberikan dampak terhadap kinerja pegawai yang menjadi lebih baik. Program program khusus dapat diterapkan oleh pimpinan untuk dapat meningkatkan budaya organisasi yang baik sehingga tercipta kinerja yang baik.

Hasil penelitian ini mendukung hasil penelitian Toni Rizal Manullang (2011) dan hasil penelitian yang dilakukan oleh Nurwati (2012) yang menyatakan Budaya Organisasi berpengaruh positif dan signifikan terhadap kinerja pegawai. Dengan demikian semakin menguatkan bahwa Budaya Organisasi sangat penting bagi 


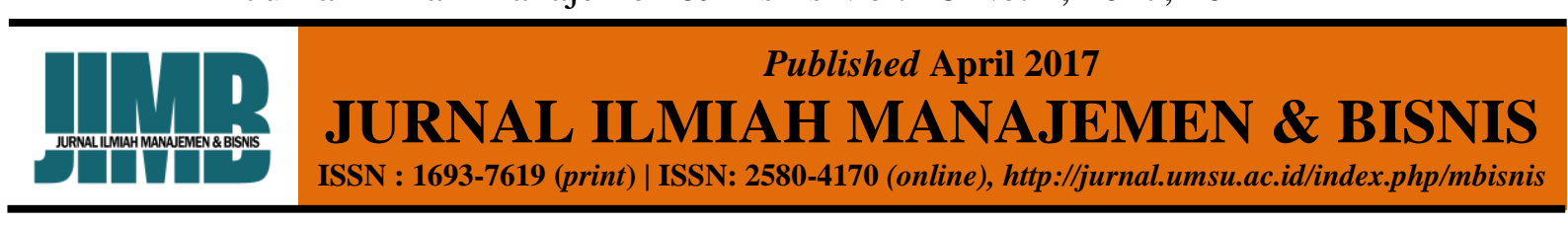

perusahaan untuk meningkatkan Kinerja pegawai.

\section{Pengaruh Perilaku Kerja Terhadap Kinerja}

Hasil menunjukkan bahwa Perilaku Kerja berpengaruh signifikan terhadap kinerja. Hal ini ditunjukkan dengan nilai signifikansi Perilaku Kerja dibandingkan dengan nilai alpha penelitian. Hasil ini menunjukkan bahwa setiap terjadinya perubahan pada perilaku kerja, maka secara langsung akan mempengaruhi kinerja pegawai. Besarnya pengaruh perilaku kerja terhadap kinerja adalah sebesar $31.2 \%$, sedangkan hubungan yang tercipta antara perilaku kerja dengan kinerja adalah hubungan yang positif dan searah. Hasil ini mengindikasikan bahwa perilaku kerja pegawai sangat penting bagi perusahaan. Ketika perilaku kerja pegawai tidak baik akan berdampak secara keseluruhan terhadap kinerja. Perilaku kerja pegawai yang dapat dijelaskan adalah ketika pegawai berani untuk bermain - main dengan peraturan sehingga memberikan celah dan pintu masuk bagi wajib pajak untuk berbuat curang. Ketika hal ini terjadi, maka secara keseluruhan kinerja pegawai menjadi sangat rendah, bahkan tindakan - tindakan seperti itu, memberikan efek yang tidak baik bagi seluruh pegawai.

Hasil penelitian ini mendukung hasil penelitian yang telah dilakukan sebelumnya oleh Toni Rizal Manullang (2011) dan penelitian yang dilakukan oleh Hattami Amar (2011) yang menyatakan bahwa secara positif dan signifikan perilaku kerja berpengaruh terhadap kinerja pegawai. Hal ini semakin menguatkan bahwa perilaku kerja sangat penting dalam meningkatkan kinerja pegawai.

\section{SIMPULAN}

Berdasarkan pada penjelasan penjelasan sebelumnya, maka dapat disimpulkan sebagai berikut:
1. Perubahan Organisasi berpengaruh signifikan terhadap kinerja karyawan di PT Sisirau Medan. Hubungan yang tercipta antara kedua variabel adalah hubungan yang positif. Pengaruh perubahan organisasi ini merupakan variabel yang paling dominan mempengaruhi kinerja pegawai.

2. Budaya Organisasi berpengaruh signifikan terhadap kinerja karyawan di PT Sisirau Medan. Hubungan yang tercipta antara kedua variabel adalah hubungan yang positif.

3. Perilaku Kerja berpengaruh signifikan terhadap kinerja karyawan di PT Sisirau Medan. Hubungan yang tercipta antara kedua variabel adalah hubungan yang positif.

4. Secara bersama - sama Perubahan Organisasi, Budaya Organisasi, dan Perilaku Kerja berpengaruh signifikan terhadap Kinerja karyawan di PT Sisirau Medan.

5. Besarnya kemampuan Perubahan Organisasi, Budaya Organisasi, dan Perilaku Kerja dalam menjelaskan kinerja adalah sebesar $79.2 \%$ sedangkan sisanya sebesar $20.8 \%$ dijelaskan oleh variabel lain yang tidak dimasukkan ke dalam model penelitian ini.

\section{Saran}

Berdasarkan hasil pembahasan, maka penulis memberikan saran - saran sebagai berikut:

1. Pimpinan PT Sisirau Medan, seharusnya memberikan instruksi kepada orang-orang yang menghadapi mutasi atau promosi untuk dapat menyelesaikan pekerjaannya sesuai dengan standar operasional prosedur yang telah ditetapkan oleh pimpinan perusahaan.

2. Pimpinan perusahaan seharusnya dapat menciptakan budaya organisasi ini lebih baik lagi. Sebab dengan budaya organisasi yang seperti ini, memberikan bentuk budaya organisasi yang sangat 
baik dengan memberikan dampak terhadap kinerja pegawai yang menjadi lebih baik. Program - program khusus dapat diterapkan oleh pimpinan untuk dapat meningkatkan budaya organisasi yang baik sehingga tercipta kinerja yang baik.

3. Pimpinan PT Sisirau Medan sebaiknya dapat melihat perilaku kerja pegawainya. Pemantauan perilaku kerja pegawai akan baik untuk semuanya. Mengkontrol perilaku kerja pegawai dapat memberikan dampak yang baik bagi kantor secara keseluruhan dan pegawai secara khusus.

\section{DAFTAR PUSTAKA}

Alwi Hasan, dkk. (2005). Kamus Besar Bahasa Indonesia. Penerbit Departemen Pendidikan Nasional Balai Pustaka, Jakarta

Anoraga, Pandji (2004), Manajemen Bisnis, Cetakan Ketiga, PT. Rhineka Cipta, Jakarta

Arikunto, Suharsimi, (2005), Prosedur Penelitian : Suatu Pendekatan Praktik, , PT. Rineka Cipta, Jakarta

David, Fred, R, (2004), Manajemen Strategis Konsep, Edisi Ketujuh, Alih bahasa Alexander Sindoro, Prehallindo, Jakara

Djohanputro, Bramantyo (2004), Restrukturisasi Perusahaan Berbasis Nilai Strateagi Menuju Keunggulan Bersaing, Penerbit PPM, Jakarta

Ghozali, Imam (2001), Aplikasi Analisis Multivariate dengan Program SPSS. Universitas Diponegoro, Semarang

Handoko T. Hani (2000), Manajemen, Edisi Kedua, BPFE, Jakarta

Hattami Amar (2011), "Pengaruh Kompetensi Dan Perilaku Kerja Terhadap Kinerja Pemeriksa Di Inspektorat Kabupaten Bangka, Tugas Akhir Program Magister (TAPM)", Universitas Terbuka, Jakarta
Kisdarto (2000), Budaya Kerja Bukan Robotisme, Majalah Manajemen No. 141, Mei, Hal. 10-11

Kreitner, Robert dan Kinicki, Angelo, (2003), Perilaku Organisasi, Terjemahan Erly Suandy, Edisi Pertama, Salemba Empat, Jakarta

Mangkunegara, AA, Anwar Prabu, (2000), Manajemen Sumber Daya Manusia Perusahaan, Penerbit Remaja Rosdakarya, Bandung

Manullang Toni Rizal (2010), "Pengaruh Restrukturisasi, Budaya Organisasi, dan Perilaku Kerja Terhadap Kinerja Pegawai Kantor Pelayanan Pajak Pratama Medan Petisah”, Tugas Akhir Program Magister (TAPM), Universitas Terbuka, Jakarta

Mathis Robert L. Dan Jackson John H. (2002), Manajemen Sumber Daya Manusia, Salemba Empat, Jakarta

Munandar (2001) Manajemen Sumber Daya Manusia dan Personalia, Penerbit Ghalia Indonesia, Jakarta

Nurwati (2012), "Pengaruh Budaya Organisasi Terhadap Perilaku Kerja dan Kinerja Karyawan Studi Pada Koperasi Unit Desa di Provinsi Sulawesi Tenggara", Jurnal Sains Manajemen. Program Magister Sain Manajemen UNPAR, Volume 1 Nomor 1, September 2012

Osborn, D \& Peter, P (2000), Memangkas Birokrasi, Edisi Revisi, Penerbit PPM Jakarta

Robbins, Stephen P, (2001), Perilaku Organisasi Konsep, Kontroversi, Aplikasi, Jilid II, Alih Bahasa Hadyana Pujaatmaka dan Benyamin Molan, Prehallindo, Jakarta (2003), Perilaku

Organisasi: Konsep Kontroversi, Aplikasi Edisi Indonesia, Edisi Revisi Penerbit PT. Prenhallindo, Jakarta

Sahyar (2009), Penilaian Kinerja dan Balas Jasa, Bahan Ajar, Program 
Pascasarjana MM-UISU, Sumatera Utara

Sastrohadiwiryo B. Siswanto, (2002), Manajemen Tenaga Kerja Indonesia, PT. Bumi Aksara, Jakarta

Sedarmayanti (1999), Restrukturisasi dan Pemberdayaan Organisasi Untuk Menghadapi Dinamika Perubahan Lingkungan: Ditinjau Dari Beberapa Aspek, Penerbit Mandar Maju, Bandung

Siagian, P. Sondang (2003), Teori Pengembangan Organisasi Edisi Revisi, Penerbit Bumi Aksara Sinar Grafika Offset, Jakarta

Sobirin Achmad (2005), "Meraih Keunggulan Melalui Pengintergrasian Sumber Daya Manusia dan Perencanaan Strategik”, Edisi Khusus, Jurnal Siasat Bisnis on Human Resources

Steven Leonardo Soegiono dan Eddy Madiono Sutanto (2013), "Restrukturisasi Organisasi di PT. Samudra Alam Raya Surabaya", Jurnal Agora Vol 1. No. 3, Universitas Kristen Petra

Sugiono. (2002),Metode Penelitian Kuantitatif, Kualitatif, dan $R \& D$. Alfabeta. Bandung

Sugiyono, (2006), Metode Penelitian Bisnis, CV. Alfabeta, Bandung

Togu Charles Edison Hutajulu (2012), "Pengaruh Kompetensi, Komitmen dan Perubahan Organisasi, Terhadap Kinerja Pegawai Negeri Sipil di Lingkungan Sekretariat Daerah Kabupaten Tapanuli Tengah”, Tugas Akhir Program Magister (TPAM), Program Pascasarjana, Universitas Terbuka, Jakarta

Tsang \& Chiu (2000), "The generic work behavior questionnaire $(G W B Q)$ : Assessment of core dimensions of generic work behavior of people with severe mental illnesses in vocational rehabilitation,
Rehabilitation Journal, Vol. 28 Number 1, Summer 2004, Page. 40-47 Yulisa Kurniawati (2003), "Analisis Pengaruh Perilaku Terhadap Kinerja Tenaga Penjual, Studi Kasus Pada Perusahaan Asuransi Jiwa di Kota Semarang”, Tesis, Program Studi Magister Majemen Universitas Diponegoro, Semarang

Wahid Sulaiman (2004), Analisis Regresi Menggunakan SPSS, Penerbit Alfabeta, Bandung

West M.A. (2000), Mengembangkan Kreativitas Dalam Organisasi, Edisi 1, Penerbit Kanisius, Yogyakarta www.depdiknas.go.id 